\title{
Laporan kasus berbasis bukti Efektivitas Transfusi Trombosit Hasil Uji Silang Serasi (Crossmatch) pada Kondisi Trombositopenia Refrakter
}

Murti Andriastuti, Novie Amelia Chozie, Syahminar Rahmani

Departemen Ilmu Kesehatan Anak Fakultas Kedokteran Universitas Indonesia Rumah Sakit Dr. Cipto Mangunkusumo, Jakarta

\begin{abstract}
Latar belakang. Penyebab imun tersering trombositopenia refrakter adalah adanya antibodi terhadap human leukocyte antigens (HLA) dan atau human platelet antigens (HPA). Salah satu strategi untuk mengidentifikasi unit trombosit yang kompatibel untuk resipien adalah dengan uji silang serasi (crossmatching).

Tujuan. Mengetahui efektivitas uji silang serasi sebagai tata laksana trombositopenia refrakter.

Metode. Penelusuran literatur secara daring, digunakan instrumen pencari Pubmed, Cochrane, Clinical key, dan Google Scholar. Kata kunci yang digunakan adalah "crossmatching", "platelet transfusion", "thrombocytopenia", "refractory", dan "efficacy".

Hasil. Terdapat 3 artikel yang relevan dengan masalah. Penelitian kohort terhadap 100 transfusi trombosit dengan uji silang serasi menunjukkan hasil rerata 24 jam jumlah trombosit pascatransfusi secara signifikan lebih tinggi pada kelompok kompatibel $(9,250 \pm 026,6)$ daripada kelompok inkompatibel $(6,757.94 \pm 2,656.5), \mathrm{p}<0.0001$. Penelitian kohort yang kedua juga menunjukkan perbedaan kenaikan jumlah trombosit pascatransfusi antara kelompok kompatibel dan inkompatibel bermakna secara signifikan $(\mathrm{p}=0,041)$. Pada penelitian kohort ketiga, transfusi trombosit inkompatibel terbukti meningkatkan risiko terjadinya respons kenaikan trombosit yang buruk pada 1 jam (OR: 5,38; $95 \%$ CI: 2,060-14,073; p<0,001), tetapi tidak pada 24 jam (OR: 1,400; CI: 0,572-3,434; $\mathrm{p}=0$,46). Terdapat perbedaan bermakna antara jumlah absolut trombosit pada 1 jam dan 24 jam pascatransfusi trombosit $(\mathrm{p}<0,001)$. Kesimpulan. Transfusi trombosit hasil uji silang serasi yang kompatibel efektif diberikan pada pasien dengan kondisi trombositopenia refrakter. Sari Pediatri 2018;20(1):50-7
\end{abstract}

Kata kunci: daring, transfusi, human leukocyte antigens (HLA)

\section{Effectiveness of Cross-matched Platelet Transfusion in Refractory Thrombocytopenia}

Murti Andriastuti, Novie Amelia Chozie, Syahminar Rahmani

Background. The most common cause of refractory thrombocytopenia is the presence of human leukocyte antigens (HLA) and/or human platelet antigens (HPA) in the recipient blood. One of the strategies to overcome the problem is platelet cross-matching test, to identify compatible platelet donor before transfusion.

Objective. To discuss the effectiveness of platelet cross-matching test in management refractory thrombocytopenia.

Methods. The literature search using an electronic database: Pubmed, Cochrane, Clinical key, and Google Scholar. Keywords: "crossmatching", "platelet transfusion", "thrombocytopenia", "refractory", dan "efficacy".

Results. There are 3 articles matched the clinical problem. First cohort study reported 24 hours post-transfusion platelet increment was significantly increased incompatible group $(9,250 \pm 026,6)$ compare to incompatible group $(6,757.94 \pm 2,656.5), p<0.0001$. The second cohort study also showed significant post-transfusion platelet increment $(\mathrm{p}=0,041)$. The last cohort study reported that incompatible platelet transfusion significantly increased the risk of increment platelet response at 1 hour post transfusion (OR: 5,38; 95\% CI: 2,060-14,073; p<0,001), but not at 24 hours (OR: 1,400; CI: 0,572-3,434; p=0,46). The post-transfusion absolute platelet count at 1 hour and 24 hours also showed a significant difference $(\mathrm{p}<0,001)$ between compatible and incompatible groups.

Conclusion. The compatible cross-matched platelet transfusion is effective in patients with refractory thrombocytopenia. Sari Pediatri 2018;20(1):50-7

Keywords: electronic database, transfusion, human leukocyte antigens (HLA)

Alamat korespondensi: Novie Amelia Chozie. Departemen Ilmu Kesehatan Anak Fakultas Kedokteran Universitas Indonesia/Rumah Sakit Dr. Cipto Mangunkusumo, Jakarta Email: novie37@gmail.com 


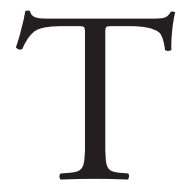

Trombosit berperan penting dalam mempertahankan hemostasis melalui pelekatan pada lokasi vaskular dan membentuk plak trombosit. ${ }^{1}$ Individu sehat memiliki kadar trombosit dalam darah $150 \times 10^{9}$ hingga $400 \times 10^{9}$ trombosit per liter. Trombositopenia dapat menyebabkan gejala perdarahan yang bervariasi dari petekiae hingga perdarahan intrakranial, perdarahan paru, dan kematian. ${ }^{2,3}$ Tiga puluh hingga $70 \%$ pasien trombositopenia dengan riwayat transfusi berulang dapat menjadi refrakter terhadap trombosit donor. ${ }^{4}$ Istilah refrakter, 2 kali kegagalan respon terhadap transfusi trombosit, menunjukkan bahwa trombosit dari donor tidak meningkatkan kadar trombosit sesuai dengan yang diharapkan, berdasarkan jumlah trombosit yang diberikan dan estimasi volume darah pasien.

Trombositopenia refrakter dapat diakibatkan oleh faktor imun dan non-imun. Penyebab non-imun lebih sering menyebabkan respons pascatransfusi yang kurang baik. Penyebab non-imun harus dievaluasi dan diatasi. Penyebab imun tersering adalah adanya antibodi terhadap human leukocyte antigens (HLA) dan atau human platelet antigens (HPA). Antibodi tersebut dapat terbentuk dari pajanan terhadap transfusi, kehamilan, atau transplantasi. Penyebab imun trombositopenia refrakter harus dievaluasi dengan mengidentifikasi adanya antibodi anti-HLA dan anti-HPA. Jika antibodi tersebut teridentifikasi, maka terdapat beberapa strategi untuk mengidentifikasi unit trombosit yang kompatibel. Salah satu strateginya adalah dengan uji silang serasi (crossmatching). ${ }^{3.6-8}$ Trombosit donor dari hasil uji silang serasi dapat diberikan pada pasien yang memiliki antibodi antiHLA dan atau anti-HPA. ${ }^{3}$ Sajian kasus berbasis bukti ini ditujukan untuk membahas efektivitas uji silang serasi sebagai tata laksana trombositopenia refrakter.

\section{Kasus}

Seorang anak perempuan usia 2 tahun 8 bulan, rujukan dari RSUD MHA, dengan keluhan perdarahan dari telinga sejak 1 bulan sebelum masuk rumah sakit (SMRS). Keluhan awal mula dirasakan pada lima bulan SMRS. Pasien terdapat demam, nyeri tulang, perdarahan gusi, buang air besar (BAB) hitam, perdarahan dari telinga, dan perut dirasakan semakin membesar. Saat itu pasien diberikan transfusi PRC dan trombosit. Pasien dirawat selama 3 minggu, diberikan antibiotik seftriakson, transfusi PRC dan trombosit. Hasil pemeriksaan darah dan apusan darah tepi menunjukkan kemungkinan leukemia. Pasien dirujuk ke RSCM untuk evaluasi dan tata laksana lebih lanjut. Saat masuk perawatan terdapat perdarahan dari telinga kanan. Keluhan disertai demam dan terdapat BAB hitam. Tidak terdapat mimisan atau gusi berdarah.

Pada pemeriksaan fisis didapatkan demam $39,9^{\circ} \mathrm{C}$. Terdapat benjolan di regio postaurikula dekstra ukuran $3 \mathrm{~cm}$. Terdapat pembesaran kelenjar getah bening (KGB) colli sinistra, kenyal, immobile, diameter $1 \mathrm{~cm}$. Terdapat pembesaran KGB di submandibula sinistra diameter $3 \mathrm{~cm}$, immobile. Mata tampak konjungtiva pucat. Jantung/paru dalam batas normal. Abdomen didapatkan hepatomegali $3 \mathrm{~cm}$ di bawah arcus costae dan $3 \mathrm{~cm}$ di bawah prosessus xyphoideus. Limpa teraba di Schuffner II. Hasil pemeriksaan laboratorium menunjukkan $\mathrm{Hb}$ 6,42 mg/dL, Ht 17,1\%, leukosit 20.200/ $\mu \mathrm{L}$, trombosit $9.680 / \mu \mathrm{L}$, hitung jenis basofil/eosinofil/neutrofil batang/ neutrofil segmen/limfosit/monosit 0/0/0/1/18/1\%, blast $80 \%$. ANC 202. Urinalisis didapatkan warna kuning keruh, $\mathrm{pH}$ 6,5, bakteri/nitrit/LEA negatif, leukosit urin 1-2/LPB, eritrosit urin 1-2/LPB. Pasien didiagnosis demam neutropenia dan leukemia akut. Pasien diberikan antibiotik seftazidim dosis sepsis, transfusi PRC target $\mathrm{Hb} 10 \mathrm{~g} / \mathrm{dL}$, transfusi trombosit $10 \mathrm{ml} / \mathrm{kg}$ tiap $24 \mathrm{jam}$ hingga perdarahan berhenti, dilakukan pemeriksaan kultur darah dan kultur urin, dipasang selang nasogastrik, aspirasi sumsum tulang, dan konsul departemen THTKL. Hasil aspirasi sumsum tulang menunjukkan leukemia limfositik akut. Hasil lenkemia phenotyping menunjukkan gambaran ALL-B. Hasil kultur darah steril, kultur urin didapatkan Klebsiella pneumonia, dan kultur tinja didapatkan Escherichia coli nonpatogen. Setelah 2 hari perawatan tidak terdapat demam. Selama 16 hari perawatan di RSCM pasien terdapat trombositopenia berulang $(5.000 / \mu \mathrm{L}, 1.000 / \mu \mathrm{L}, 15.000 / \mu \mathrm{L})$ dengan atau tanpa klinis mimisan dan $\mathrm{BAB}$ hitam. Pasien diberikan transfusi trombosit berulang. Antibiotik diganti dengan meropenem dan ditambahkan antijamur flukonazol. Pasien dilakukan kultur darah jamur dengan hasil tidak ditemukan jamur. Klinis pasien perbaikan dan dimulai pemberian prednison. Evaluasi darah perifer lengkap terakhir menunjukkan trombositopenia $(11.000 / \mathrm{uL})$ tanpa klinis perdarahan. Pasien direncanakan transfusi trombosit dengan uji silang serasi (crossmatch). Namun, pasien diberikan transfusi trombosit biasa karena 
keterbatasan biaya. Pasien rawat jalan dan direncanakan kemoterapi pada kontrol berikutnya.

\section{Masalah klinis}

Pasien dengan klinis perdarahan, trombositopenia berulang meskipun telah diberikan transfusi trombosit serial. Dalam pemantauan tidak terdapat tanda sepsis. Kasus tersebut menimbulkan pertanyaan klinis sebagai berikut: Bagaimana efektivitas transfusi trombosit hasil uji silang serasi pada kondisi trombositopenia refrakter?

Oleh karena itu, dapat ditentukan PICO pada penelitian ini adalah:

Population : pasien dengan trombositopenia refrakter Intervention : pemberian transfusi trombosit hasil uji silang serasi yang kompatibel

Comparison : pemberian transfusi trombosit hasl uji silang serasi inkompatibel

Outcome : efektivitas

\section{Metode}

Untuk menjawab masalah di atas, prosedur pencarian pustaka dilakukan dengan menelusuri literatur secara daring, digunakan instrumen pencari Pubmed, Cochrane, Clinical key, dan Google Scholar. Kata kunci yang digunakan adalah "crossmatching", "platelet trans fusion", "thrombocytopenia", "refractory", dan "efficacy" dengan menggunakan batasan: bahasa pengantar adalah bahasa Inggris, publikasi literatur dalam rentang waktu 10 tahun terakhir, serta penelitian dengan penelitian uji coba klinis, telaah sistematis atau meta-analisis. Berdasarkan metode penelusuran dengan kriteria di atas, didapatkan 30 artikel, tetapi setelah ditelaah lebih lanjut hanya terdapat 3 artikel yang dianggap relevan dengan masalah di atas. Levels of Evidence ditentukan berdasarkan klasifikasi yang dikeluarkan oleh Oxford Centre for Evidence-Based Medicine.? Alur pemilihan literatur digambarkan sesuai bagan pada Tabel 1 dan Diagram 1.

Penelusuran literatur dengan metode di atas menghasilkan artikel yang tertera pada Tabel

Tiga puluh artikel yang sudah dipilih menjalani seleksi dengan alur sebagai berikut:

Elhence $\mathrm{dkk}^{10}$ melakukan uji (level of evidence 2b) untuk mengetahui efektivitas pemberian transfusi trombosit uji silang serasi kompatibel pada subyek dengan trombositopenia refrakter. Seratus transfusi trombosit aferesis diberikan kepada 31 pasien. Subyek didefinisikan refrakter bila corrected count increment (CCI) 24 jam pascatransfusi kurang dari $5 \times 10^{9} / \mathrm{L}$ setelah 2 kali pemberian transfusi trombosit. Subyek dengan klinis sepsis atau splenomegali tidak diikutsertakan pada penelitian ini. Median usia subyek adalah 32 tahun (kisaran usia 6 hingga 75 tahun). Dua puluh satu $(67,7 \%)$ subyek didiagnosis anemia aplastik dan $10(23,3 \%)$ subyek didiagnosis leukemia mieloblastik akut. Subyek dalam studi ini sebelumnya telah menerima 81,6 (kisaran 20-172) unit transfusi trombosit. Uji silang serasi dilakukan dengan metode ELISA. Hasil uji silang serasi menunjukkan inkompatibel pada 56 (56\%) darah donor. Duapuluh dua $(39,3 \%)$ memiliki respon CCI yang buruk dan $34(60,7 \%)$ memiliki respon CCI yang baik. Hasil uji silang serasi didapatkan kompatibel pada 44 (44\%) darah donor). Empatpuluh satu (93,2\%) memiliki respon CCI yang baik, sedangkan $3(6,8 \%)$ memiliki respons CCI yang buruk. Hasil penelitian ini menunjukkan bahwa respon baik dan buruknya

Tabel 1. Hasil penelusuran literatur

\begin{tabular}{llcc}
\hline Database & Kata kunci penelusuran & $\begin{array}{c}\text { Jumlah artikel yang } \\
\text { didapatkan }\end{array}$ & Artikel yang relevan \\
\hline Pubmed & $\begin{array}{l}\text { "crossmatching" AND "platelet transfusion" AND } \\
\text { "refractory thrombocytopenia" AND "efficacy" }\end{array}$ & 12 & 3 \\
Cochrane & $\begin{array}{l}\text { "crossmatching" AND "platelet transfusion" AND } \\
\text { "refractory thrombocytopenia" AND "efficacy" }\end{array}$ & 2 & 2 \\
Clinical key & $\begin{array}{l}\text { "crossmatching" AND "platelet transfusion" AND } \\
\text { "refractory thrombocytopenia" AND "efficacy" }\end{array}$ & 0 & 0 \\
Google scholar "crossmatching" AND "platelet transfusion" AND & 16 & 3 \\
& "refractory thrombocytopenia" AND "efficacy"
\end{tabular}


Crossmathching platelet transfusion

273

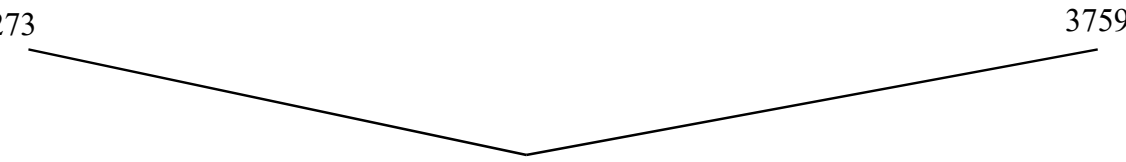

(Crossmatching* OR cross-matched) AND (Platelet transfusion) AND

(Refractory thrombocytopenia) AND (Efficacy)

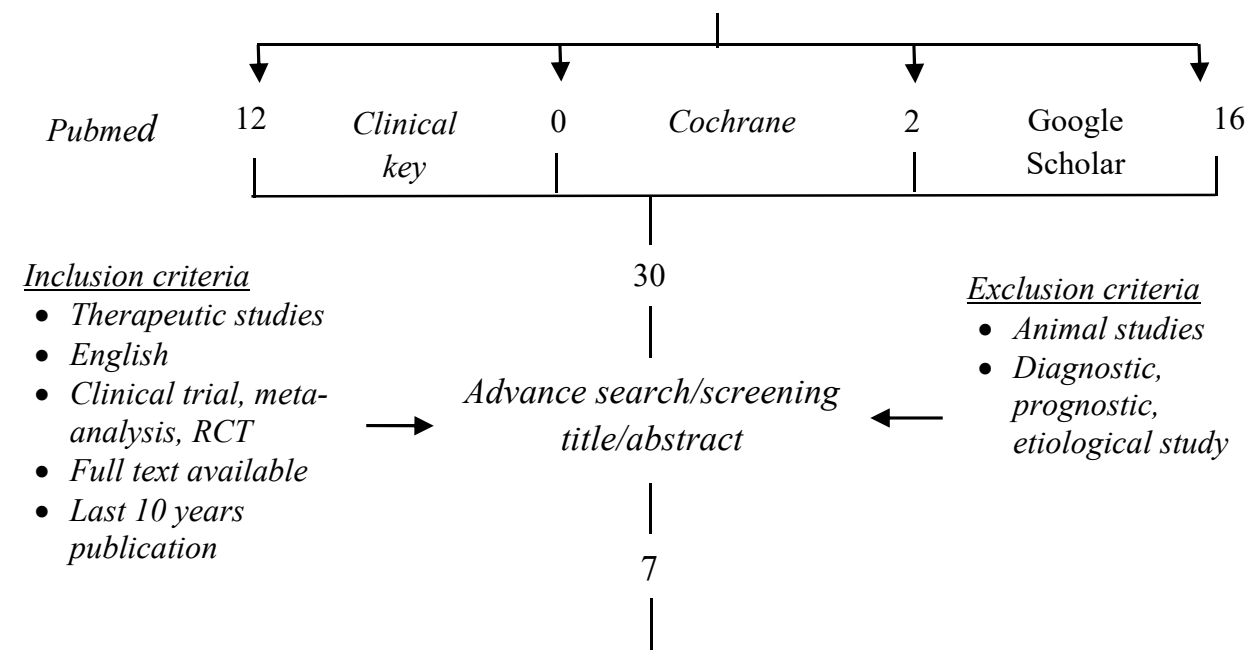

Screening full text

3

Diagram 1. Alur pemilihan literatur

24 jam CCI pascatransfusi pada kelompok kompatibel dan inkompatibel adalah berbeda bermakna $(\mathrm{p}=0,000)$. Hasil CCI (rerata \pm SD) 24 jam pascatransfusi secara signifikan lebih tinggi pada kelompok kompatibel $(9,250 \pm 026,6)$ daripada kelompok inkompatibel $(6,757.94 \pm 2,656.5)(\mathrm{p}<0.0001)$.

Sayed $\mathrm{dkk}^{11}$ melakukan penelitian terhadap uji silang serasi trombosit menggunakan flowsitometri. Penelitian ini dilakukan pada 39 pasien leukemia akut, terdiri dari 26 dewasa dan 13 anak. Pasien ini menerima 60 transfusi trombosit kompatibel $\mathrm{ABO}$ aferesis leukoreduksi dengan kisaran pemberian trombosit 1 hingga 4 kali untuk setiap pasien. Rerata kadar trombosit yang ditransfusikan yaitu $5,03 \pm 1,13 \times 10^{11}$. Efektivitas transfusi trombosit dievaluasi menggunakan
CCI yang dihitung pada 60 menit dan 18-24 jam pascatransfusi. Respons buruk didefinisikan sebagai CCI pada 60 menit dan pada 18-24 jam pascatransfusi dibawah 4.500-5.000 dan 2.500 per mikroliter. Pada semua transfusi dimonitor faktor klinis seperti splenomegali, perdarahan aktif, sepsis, dan demam lebih dari $38,5^{\circ} \mathrm{C}$. Median usia pasien anak, yaitu $8 \pm 5,8$ tahun dengan median kadar trombosit sebelum transfusi $15,69 \pm 9,28 \times 10^{9} / \mu \mathrm{L}$. Respons CCI yang baik didapatkan pada $12(71,3 \%)$ dari 15 subyek anak pada kelompok kompatibel. Respons CCI yang buruk terdapat pada $2(100 \%)$ subyek anak pada kelompok inkompatibel. Perbedaan hasil CCI antara kelompok kompatibel dan inkompatibel bermakna secara signifikan $(\mathrm{p}=0,041)$. 
Salama $\mathrm{dkk}^{12}$ menguji efektivitas transfusi trombosit hasil uji silang serasi yang kompatibel pada pasien trombositopenia refrakter. Kriteria refrakter, yaitu CCI 1 jam atau 24 jam pascatransfusi kurang dari 5.000 atau $2.500 / \mu \mathrm{L}$ setelah 2 kali pemberian transfusi trombosit. Pada semua transfusi dimonitor

Tabel 2. Rangkuman studi

\begin{tabular}{|c|c|c|c|}
\hline Artikel & Elhence dkk (2014) & Sayed dkk (2011) & Salama dkk (2014) \\
\hline Desain penelitian & uji kohort & uji kohort & uji kohort \\
\hline Periode & Juni 2010- Juli 2012 & 2010 & Mei 2011-Desember 2012 \\
\hline Lokasi & India & Mesir & Mesir \\
\hline Partisipan & $\begin{array}{l}31 \text { pasien dengan } 100 \text { transfusi } \\
\text { trombosit } \\
\text { median usia } 32 \text { tahun }(6-75 \\
\text { tahun) }\end{array}$ & $\begin{array}{l}39 \text { pasien } \\
\text { ( } 26 \text { dewasa dengan } 43 \text { transfusi } \\
\text { trombosit, } 13 \text { anak dengan } 17 \\
\text { transfusi trombosit) } \\
\text { median usia anak } 8 \pm 5,8 \text { tahun }\end{array}$ & $\begin{array}{l}40 \text { pasien dengan } 120 \text { transfusi } \\
\text { trombosit } \\
\text { median usia } 37,6 \pm 13,35 \text { tahun }\end{array}$ \\
\hline Intervensi & $\begin{array}{l}\text { transfusi trombosit aferesis hasil } \\
\text { uji silang serasi yang kompatibel }\end{array}$ & $\begin{array}{l}\text { transfusi trombosit aferesis hasil } \\
\text { uji silang serasi yang kompatibel }\end{array}$ & $\begin{array}{l}\text { transfusi trombosit hasil uji silang } \\
\text { serasi yang kompatibel pada pasien } \\
\text { yang refrakter terhadap donor random }\end{array}$ \\
\hline Luaran & $\begin{array}{l}\text { corrected count increment }(\mathrm{CCI}) \\
24 \text { jam pascatransfusi }\end{array}$ & $\begin{array}{l}\text { CCI } 1 \text { jam dan } 18-24 \text { jam } \\
\text { pascatransfusi }\end{array}$ & CCI 1 jam dan 24 jam pascatransfusi \\
\hline Bias & tidak ada randomisasi & tidak ada randomisasi & tidak ada randomisasi \\
\hline Level of evidence & $2 \mathrm{~b}$ & $2 \mathrm{~b}$ & $2 \mathrm{~b}$ \\
\hline
\end{tabular}

Tabel 3. Validitas dan Importance

\begin{tabular}{|c|c|c|c|}
\hline Artikel & Elhence dkk (2014) & Sayed dkk (2011) & Salama dkk (2014) \\
\hline Randomisasi & Tidak & Tidak & Tidak \\
\hline Keseragaman di awal penelitian & TIdak dijelaskan & Tidak dijelaskan & Tidak dijelaskan \\
\hline Persamaan perlakuan & $\mathrm{Ya}$ & Ya & Ya \\
\hline Pengukuran & Objektif & Objektif & Objektif \\
\hline Kesimpulan & Sahih (valid) & Sahih (valid) & Sahih (valid) \\
\hline Importance & $\begin{array}{c}\text { CCI } 24 \text { jam pascatransfusi } \\
\text { CER: } 39,3 \% \\
\text { EER: } 6,8 \% \\
\text { RR: } 0,17 \\
\text { RRR: } 0,83(83 \%) \\
\text { ARR: } 32,5 \% \\
\text { NNT: } 1,2\end{array}$ & $\begin{array}{l}\text { CCI pada grup anak } \\
\text { CER: } 100 \% \\
\text { EER: } 26,7 \% \\
\text { RR: } 0,27 \\
\text { RRR:0,73 }(73 \%) \\
\text { ARR: } 73 \% \\
\text { NNT: } 1,36\end{array}$ & $\begin{array}{c}\text { CCI pada } 1 \text { jam pascatransfusi } \\
\text { CER: } 67 \% \\
\text { EER: } 27 \% \\
\text { RR: } 0,4 \\
\text { RRR: } 0,6(60 \%) \\
\text { ARR: } 40 \% \\
\text { NNT: } 2,5\end{array}$ \\
\hline & $\mathrm{p}=0,0000$ & $\mathrm{p}=0,041$ & $\mathrm{p}<0,001$ \\
\hline & & & $\begin{array}{c}\text { CCI pada } 24 \text { jam pascatransfusi } \\
\text { CER: } 50 \% \\
\text { EER: } 41,7 \% \\
\text { RR: } 0,83 \\
\text { RRR: } 0,17(17 \%) \\
\text { ARR: } 8,3 \% \\
\text { NNT: } 1,2\end{array}$ \\
\hline & & & $\mathrm{p}=0,461$ \\
\hline
\end{tabular}


Murti Andriastuti dkk: Efektivitas transfusi trombosit hasil uji silang serasi (crossmatch) pada kondisi trombositopenia refrakter

Tabel 4. Kemamputerapan

\begin{tabular}{lccc}
\hline Artikel & $\begin{array}{c}\text { Elhence dkk } \\
(2014)\end{array}$ & $\begin{array}{c}\text { Sayed dkk } \\
(2011)\end{array}$ & $\begin{array}{c}\text { Salama dkk } \\
(2014)\end{array}$ \\
\hline Apakah karakteristik pasien kita serupa dengan subyek uji klinis yang ditelaah? & Ya & Ya & Ya \\
Apakah intervensi dapat dilakukan di tempat saya bekerja? & Ya & Ya & Ya \\
Apakah keuntungannya lebih besar dibandingkan kerugian? & Ya & Ya & Ya \\
\hline
\end{tabular}

adanya splenomegali, perdarahan aktif, sepsis, demam lebih dari $38^{\circ} \mathrm{C}$. Rerata usia pasien yaitu $37,6 \pm 13,35$ tahun. Limapuluh persen subyek didiagnosis leukemia mieloid akut. Uji silang serasi dilakukan dengan metode ELISA. Unit donor yang dilakukan uji silang serasi sebanyak 406 unit. Secara keseluruhan 83,7\% (340/406) kompatibel dan 16,3\% (66/406) inkompatibel. Seratus duapuluh 120 transfusi trombosit (kisaran 1 hingga 4 kali per pasien) diberikan pada penelitian ini. Semua trombosit kompatibel (96 transfusi) dan inkompatibel (24 transfusi) diberikan kepada pasien. Rerata jumlah absolut trombosit 1 jam pascatransfusi pada kelompok kompatibel adalah $28,33 \pm 16,3\left(\mathrm{x} 10^{9} / \mathrm{L}\right)$ dan pada kelompok inkompatibel adalah $14,8 \pm 5,82\left(\mathrm{x} 10^{9} / \mathrm{L}\right)$. Rerata jumlah trombosit pretransfusi adalah $13,48 \pm 10,62\left(\times 10^{\%} / \mathrm{L}\right)$ pada kelompok kompatibel dan 10,76 $\pm 6,67$ (x10\%/L). Rerata jumlah absolut trombosit 24 jam pascatransfusi pada kelompok kompatibel adalah 23,28 $\pm 15,87\left(\mathrm{x} 10^{9} / \mathrm{L}\right)$ dan pada kelompok inkompatibel adalah $11,97 \pm 5,28$ $\left(\mathrm{x} 10^{9} / \mathrm{L}\right)$. Respons baik (CCI $>5000$ pada 1 jam dan $>2500$ pada 24 jam) didapatkan 72,9\% (70/96) dan 58,3\% (56/96) kelompok kompatibel pada 1 jam dan 24 jam. Terdapat 33,3\% (8/24) dan 50\% (12/24) respons baik di kelompok inkompatibel pada 1 jam dan 24 jam. Transfusi trombosit inkompatibel meningkatkan risiko terjadinya respons CCI yang buruk pada 1 jam (OR: 5,38; 95\% CI: 2,060-14,073; $\mathrm{p}<0,001)$, tetapi tidak pada 24 jam (OR: 1,400; CI: $0,572-3,434 ; \mathrm{p}=0,46)$. Terdapat perbedaan bermakna antara jumlah absolut trombosit pada 1 jam dan 24 jam pascatransfusi trombosit $(\mathrm{p}<0,001)$.

\section{Pembahasan}

Transfusi trombosit merupakan terapi yang penting untuk pasien dengan keganasan, kegagalan sumsum tulang belakang, transplantasi sel stem. Penggunaan transfusi trombosit telah terbukti menurunkan mortalitas akibat perdarahan pada pasien dengan leukemia akut pada tahun 1950 dan penggunaan terapi ini semakin meningkat sejak saat itu. ${ }^{6}$ Pada umumnya, trombosit ditransfusikan untuk mencegah perdarahan pada pasien trombositopenia akibat kemoterapi atau yang menjalani transplantasi sel stem hematopoiesis. Transfusi trombosit juga diberikan pada pasien yang tidak trombositopenia tetapi memiliki fungsi trombosit yang abnormal. Beberapa kondisi yang membutuhkan transfusi trombosit antara lain: (1) penurunan produksi (kemoterapi, anemia aplastik dan radiasi; (2) peningkatan destruksi (koagulasi intravaskular diseminata, purpura trombositopenia trombosis, hemangioma kavernosis, trombositopenia autoimun); (3) dilusi; (4) transfusi massif; (5) disfungsi trombosit akibat panajan obat, defek trombosit kongenital, efek metabolit, atau uremia. ${ }^{13}$

Terdapat risiko rendah untuk terjadinya perdarahan spontan berat jika kadar trombosit lebih dari 20.000/ $\mu \mathrm{L}$. Namun, risiko meningkat jika kadar trombosit kurang dari jumlah tersebut. Oleh karena kurangnya uji klinis yang meyakinkan, telah menjadi praktik sehari-hari untuk melakukan transfusi trombosit sebagai pencegahan perdarahan berat pada kadar trombosit < 20.000/ $\mu \mathrm{L} .{ }^{6}$ National Institutes of Health Consensus Conference merekomendasikan kadar trombosit $20.000 / \mu \mathrm{L}$ sebagai batas untuk memberikan transfusi trombosit profilaksis. ${ }^{14}$ Beutler merekomendasikan penurunan batas trombosit untuk profilaksis dan saat ini banyak dokter dan panduan rumah sakit menggunakan batas 10.000 atau 5.000/ $\mu \mathrm{L}$ sebagai indikasi diberikannya transfusi profilaksis pada pasien yang stabil. ${ }^{15-17}$

Efek klinis transfusi trombosit dapat dimonitor melalui viabilitas, survival, dan fungsi trombosit. Viabilitas biasanya dievaluasi dengan corrected count increment (CCI) awal, sedangkan survival dinilai dari corrected count increment lambat, yaitu pada 18-24 jam pascatransfusi. Fungsi trombosit dimonitor dengan dilakukan tes hemostasis dan fungsi trombosit, seperti thromboelastography (TEG). Keberhasilan transfusi trombosit didefinisikan sebagai CCI $>7,5 \times 10^{\%} / \mathrm{L}$ pada 
1 jam pascatransfusi dan $\mathrm{CCI}>4,5 \times 10^{9} / \mathrm{L}$ setelah $20-24$ jam pascatransfusi. ${ }^{17,18}$ Rumus perhitungan CCI yaitu

$$
\mathrm{CCI}=\frac{(\text { PLT post }- \text { PLTpre }) \times \text { BSA }}{\text { dose of platelet transfused } \times 10^{11}}
$$

PLTpost: trombosit $(/ \mu \mathrm{L})$ pascatransfusi, PLTpre: trombosit $(/ \mu \mathrm{L})$ pascatransfusi

BSA: body surface area $\left(\mathrm{m}^{2}\right)$, dose of platelet transfused: dosis trombosit yang ditransfusikan

Trombositopenia refrakter didefinisikan sebagai kegagalan respons berulang terhadap transfusi trombosit 2 kali atau lebih berturut-turut. Refrakter didefinisikan sebagai nilai CCI $4,5-7,5 \times 10^{9} / \mathrm{L}$ pada $10-60$ menit pascatransfusi dan $2,5-4,5 \times 10^{\%} / \mathrm{L}$ pada $18-24$ jam pascatransfusi. ${ }^{17}$ Sebanyak $30-70 \%$ pasien menjadi refrakter terhadap transfusi trombosit karena beberapa faktor, seperti demam/infeksi, koagulopati intravaskular diseminata, dan antibodi atau toksisitas terkait obat. Namun, 20\% pasien yang refrakter dipengaruhi oleh adanya mekanisme imun. Mekanisme imun tersering adalah adanya antibodi terhadap human leucocyte class I (HLA 1) dan human platelet antigens (HPA) yang diekspresikan oleh trombosit donor sehingga memercepat pembersihan trombosit dalam darah setelah transfusi berulang. Terdapat beberapa kondisi yang dapat menyebabkan trombositopenia, misalnya: faktor klinis akibat splenomegali, infeksi, demam dan perdarahan; obat-obatan seperti amfoterisin, vankomisin, siprofloksasin dan heparin; dan jenis kelamin pasien; faktor imun pasien seperti antibodi, HLA, dan eritrosit; dan disfungsi trombosit seperti pajanan obat, defek trombosit kongenital, efek metabolit dan uremia. ${ }^{6}$

Tatalaksana trombositopenia refrakter yang diakibatkan oleh proses imun adalah dengan mengevaluasi adanya antibodi HLA dan HPA. Jika sudah diidentifikasi, terdapat beberapa strategi untuk mengidentifikasi trombosit yang kompatibel, antara lain HLA matching dan crossmatching (uji silang serasi). HLA matching dilakukan jika tipe HLA resipien diketahui. Trombosit donor dengan tipe HLA yang identik atau sama harus dicari dan diberikan. Oleh karena trombositopenia refrakter biasanya disebabkan oleh antigen HLA kelas I, HLA-A, dan B, matching hanya dilakukan pada lokus-lokus ini. Keterbatasan dari
HLA matching ini adalah keterbatasan produk. Untuk mendapatkan trombosit yang sesuai HLAnya, kedua resipien dan donor harus dicari tipe HLAnya. Hal ini membutuhkan lebih banyak biaya dan keterlambatan dalam penyediaan trombosit. ${ }^{3}$

Trombosit yang dihasilkan dari uji silang serasi (crossmatching) berguna untuk pasien dengan antibodi anti-HLA, anti-HPA, antiplatelet glycoprotein, dan anti-ABO. Beberapa metode digunakan untuk uji silang serasi, tetapi pada umumnya melibatkan inkubasi trombosit donor dengan plasma resipien dan dilakukan tes untuk melihat interaksinya. ${ }^{18}$ Uji silang serasi memungkinkan pemilihan trombosit donor secara cepat dan efektif dan dapat dilakukan dalam beberapa jam. Selain itu, metode ini dapat dilakukan pada blood center (pusat darah) dalam jumlah besar dan waktu yang singkat. Trombosit yang inkompatibel diprediksi menyebabkan respons yang buruk pada 90\% transfusi. Oleh karena kemungkinan perubahan reaktivitas alloantibodi, uji silang serasi harus dilakukan dari contoh darah baru resipien setiap 72 jam.,19

Transfusi trombosit hasil uji silang serasi diketahui memberikan efek corrected count increment (CCI) yang baik pada pasien dengan trombositopenia refrakter. Oleh karena uji silang serasi merupakan ilmu dasar dalam bidang transfusi, penulis tetap melakukan telaah terhadap penelitian yang merekrut subyek dewasa. Hasil penelitian yang dilakukan oleh Elhence ${ }^{10}$ menunjukkan bahwa transfusi trombosit hasil uji silang serasi yang kompatibel memiliki respons CCI secara signifikan lebih tinggi dibandingkan transfusi trombosit inkompatibel. Perbedaan respons CCI tersebut berbeda secara signifikan $(\mathrm{p}<0,001)$. Sayed ${ }^{11}$ melakukan penelitian terhadap kelompok anak dan mendapatkan bahwa respons CCI pada kelompok yang diberikan transfusi trombosit yang kompatibel dibandingkan dengan kelompok inkompatibel adalah berbeda bermakna $(p=0,04)$. Salama ${ }^{12}$ menunjukkan bahwa CCI pada 1 jam pascatransfusi berbeda bermakna, sedangkan CCI 24 jam pascatransfusi tidak berbeda bermakna. Adanya faktor nonimun dipikirkan memengaruhi hasil ini CCI pada penelitian Salama. Berdasarkan ketiga artikel yang telah ditelaah transfusi trombosit hasil uji silang serasi yang kompatibel efektif bila diberikan pada pasien dengan kondisi trombositopenia refrakter. Namun, hingga saat ini belum ada panduan pada praktik klinis sehari-hari di Indonesia untuk dilakukannya perhitungan CCI 
pada kondisi trombositopenia refrakter secara rutin ataupun dilakukannya uji silang serasi pada kondisi trombositopenia refrakter.

\section{Kesimpulan}

Transfusi trombosit hasil uji silang serasi yang kompatibel efektif diberikan pada pasien dengan kondisi trombositopenia refrakter.

\section{Saran}

Kondisi refrakter terhadap transfusi trombosit merupakan proses yang kompleks dan merupakan tantangan dalam tata laksana pasien dengan trombositopenia. Untuk mengetahui adanya trombositopenia refrakter perlu dilakukan perhitungan corrected count increment (CCI) secara rutin. Jika CCI kurang dari yang diharapkan maka tes untuk menilai adanya antibodi anti-HLA dan anti-HPA harus dilakukan, salah satunya dengan metode uji silang serasi.

\section{Daftar pustaka}

1. Lochowicz AJ, Curtis BR. Clinical applications of platelet antibody and antigen testing. Lab Med 2011;42:687-92.

2. Blajchman MA. Platelet transfusions: an historical perspective. Hematology Am Soc Hematol Educ Program 2008;1:197.

3. Forest SK, Hod EA. Management of the platelet refractory patient. Hematol Oncol Clin N Am 2016;30:665-77.

4. Heddle NM, Cook RJ, Sigouin C, Slichter SJ, Murphy M, Rebulla P, dkk. A descriptive analysis of international transfusion practice and bleeding outcomes in patients with acute leukemia. Transfusion 2006;46:903-11.

5. Rebulla P, Morelati F, Revelli N, Villa MA, Paccapelo C, Nocco A, dkk. Outcomes of an automated procedure for the selection of effective platelets for patients' refractory to random donors based on crossmatching locally available platelet products. $\mathrm{Br}$
J Haematol-. 2004;125:83-9.

6. Stroncek DF, Rebulla P. Platelet transfusion. Lancet-. 2007;370:427-38.

7. Vassallo RR. New paradigms in the management of alloimmune refractoriness to platelet transfusions. Curr Opin Hematol-. 2007;14:655-63.

8. Marwaha N, Sharma R. Consensus and controversies in platelet transfusion. Transfus Apher Sci-. 2009;41:127-33.

9. Oxford Centre of Evidence-Based Medicine. Levels of Evidence. 2011. Diakses pada pada tanggal 20 Oktober 2017. Diunduh dari: http://www.cebm.net/wp-content/ uploads/2014/06/CEBM-Levels-of-Evidence-2.1.pdf.

10. Elhence P, Chaudhary R, Nityanand S. Cross-matchcompatible platelets improve corrected count increments in patients who are refractory to randomly selected platelets. Blood Transfus 2014;12:180-6.

11. Sayed D, Bakry R, El-Sharkawy N, Zahran A, Khalaf M. Flow cytometric platelet cross-matching to predict platelet transfusion in acute leukemia. J Clin Apher 2011;26: 23-8.

12. Salama OS, Aladl DA, El Ghannam D, Elderiny WE. Evaluation of platelet cross-matching in the management of patients refractory to platelet transfusions. Blood Transfus 2014;12:187-94.

13. McCullough J. Overview of platelet transfusion. Semin Hematol. 2010;3:235-42.

14. Members of the Consensus Development Panel. Platelet transfusion therapy. JAMA 1987;257:1777-80.

15. Beutler E. Platelet transfusions: the $20,000 / \mathrm{mL}$ trigger. Blood 1993;81:1411-3.

16. Stanworth SJ, Hyde C, Brunskill S, Murphy MF. Platelet transfusion prophylaxis for patients with haematological malignancies: where to now? Br J Haematol 2005; 131:588-95.

17. Apelseth T, Hervig T, Bruserud O. Current practice and future directions for optimization of platelet transfusions in patients with severe therapy-induced cytopenia. Blood Rev 2011; 25:113-22.

18. Guidelines for the use of platelet transfusions. $\mathrm{Br} \mathrm{J}$ Haematol 2003;122:10-23.

19. Kopko PM, Warner P, Kresie L, Pancosca C. Methods for the selection of platelet products for alloimmune-refractory patients. Transfusion 2015;55:235-44. 